\title{
DEVELOPMENT OF A SENSOR-BASED DIKE MONITORING SYSTEM FOR COASTAL DIKES
}

\author{
Verena Krebs ${ }^{1}$, Till Quadflieg ${ }^{2}$, Christian Grimm ${ }^{1}$, Max Schwab ${ }^{2}$, Holger Schüttrumpf ${ }^{1}$ \\ Sea and estuarine dikes are one of the most important structures when it comes to coastal protection in Germany. \\ Therefore, the implementation of sea dike monitoring systems is of great value to improve the reliability of flood \\ protection. The interdisciplinary research project, EarlyDike, attempts to develop an innovative early warning system, \\ which works not only based on water level forecasts, but also considers wave load, improved storm surge monitoring, \\ and inner dike conditions. The implementation of a web-based Geo-Portal, which integrates the information generated \\ by sensors and numerical simulations, enables decision makers to access reliable real-time data. Thereby, the intended \\ sensor- and risk-based early warning system allows in time warnings and improves present disaster prevention and \\ management. Objective of this paper is to depict the integration of sensor-based dike monitoring within the project.
}

Keywords: early warning system, dike monitoring, smart geotextiles

\section{INTRODUCTION}

Severe flood events across the World (e.g. Hurrciane Katrina 2005) and in Germany (e.g. North Sea flood 1962, Cyclone Xaver 2013) regularly demonstrate the destructive force of water masses. Dikes play an important role in protecting coastal areas against the destructive forces emanating from ocean water. In case of a flood event they act as barriers, that keep the water from entering the landward side. In this process, the water level on the waterside of a dike rises and hydraulic loads on the dike increase. If loads on a dike - not only induced by the water level rise but also by wind, waves and ice - exceed the design load, a variety of failure mechanisms may occur. However, due to cascading effects (simultaneous occurrence of various loads) or local inhomogenities or damages of the structure itself, the dike may even fail before the design load is reached. Dike failure leads to unwanted and extensive flooding of the protected areas.

In the northern part of Germany 1,083 $\mathrm{km}$ of dikes protect the low lying coastal areas from being flooded (Schüttrumpf 2008). This does not yet consider additional thousands of kilometers of dikes along rivers. To guarantee the stability of all these dikes and thereby guarantee the safety of all the assets they protect, a reliable dike monitoring is inevitable. Nowadays visual safety inspections, mainly by foot, are the major safety assessment tool in Germany. Trained officials walk the dikes and look for anomalies. Under storm conditions this type of assessment is not possible. Furthermore, it does not yield reliable results under non-storm conditions as some failure mechanisms (e.g. piping) are not visible in their early stages (Bersan et al. 2015).

Therefore, the implementation of dike monitoring systems is of great value for improving the reliability of flood protection structures. Integrated in reliable early warning systems (EWS) they can help to prevent dike failure as they can direct emergency repairs to critical areas within the dike line. In case a dike failure cannot be prevented, EWS permit evacuation processes at an early stage and thereby protect humans and assets. The interdisciplinary research project, EarlyDike, attempts to develop an innovative early warning system for sea dikes in Germany, which works - in contrast to existing EWS not only based on water level forecasts, but also considers wave load, improved storm surge monitoring, and inner dike conditions. Objective of this paper is to depict the integration of sensor-based dike monitoring by the use of smart geotextiles, which is part of work package 3 within the EarlyDike project.

\section{STATE OF THE ART}

\section{Dike Failure}

Set-up of an early warning system requires an excellent understanding of the performance and possible failure mechanisms of sea dikes. Sea dikes are loaded by high water levels, currents, ice, and wind waves resulting in processes such as wave run-up, wave overtopping, wave impacts, and seepage of the dike. These processes may result in many different failure mechanisms such as turf erosion, sliding, break outs, and partial or total dike breaches.

Dike failure in general can be described as the inability of the structure to achieve a defined performance threshold (e.g. Allsop et al. 2007). Furthermore, it is possible to distinguish between three

\footnotetext{
1 Institute of Hydraulic Engineering and Water Resources Management, RWTH Aachen University, Mies-van-der-

Rohe-Str. 17; 52056 Aachen, Germany

2 Institut für Textiltechnik, RWTH Aachen University, Otto-Blumenthal-Str. 1, 52056 Aachen, Germany
} 
different stages of dike failure: dike deterioration, damage, and collapse (Simm et al. 2012a). Deterioration results from long-term processes greater than a single load event that change the state of the dike structure and increase the risk of failure probability. In this context, damage refers to short-time failures, which appear after a single loading event often given the already deteriorated state of the dike. In combination with high loads, damage can lead to dike breach or collapse, which describe a structural failure of the dike before the design load is reached. In contrast to the three above-mentioned mechanisms, functional or performance failure appears once the design load of the structure is exceeded.

Schüttrumpf and Oumeraci (2004) as well as Allsop et al. (2007) investigated sea dike failures based on an extensive literature review and documents from severe storm surges in the past. They derived the main stress and resistance factors influencing dike failures and described the main failure mechanisms of sea dikes separately for the seaward slope and the landward slope. The occurrence of a failure is often initiated by other (meteorological, geometrical, soil, biological and other) factors weakening the resistance of the dike. Therefore, the real resistance of a sea dike against wave and current attack during storm surges is difficult to determine and not identical to the design resistance. Since the real resistance is time-dependent and so far mostly unknown, a real-time early warning system may help to identify any damaged dike section, which has become too weak to withstand extreme storm surges (see also Fig. 2).

A dike breach is not a sudden event and develops over time. Fig. 1 shows the temporal development of a dike breach initiated from the seaward side and from the landward side. Dike breaches initiated from the seaward side result from wave impacts and break outs of the clay cover. The seaward clay cover is destroyed and finally the sandy core of the dike is free and not able to withstand any wave attack. Finally, this results in a fast development of a dike breach. A dike breach from the landward side is often initiated by wave overtopping or overflow. The clay cover is either eroded or infiltrated by water resulting in a loss of stability of the landward clay cover. If the clay cover of the landward slope is destroyed, the sand core can be washed out and a dike breach develops.
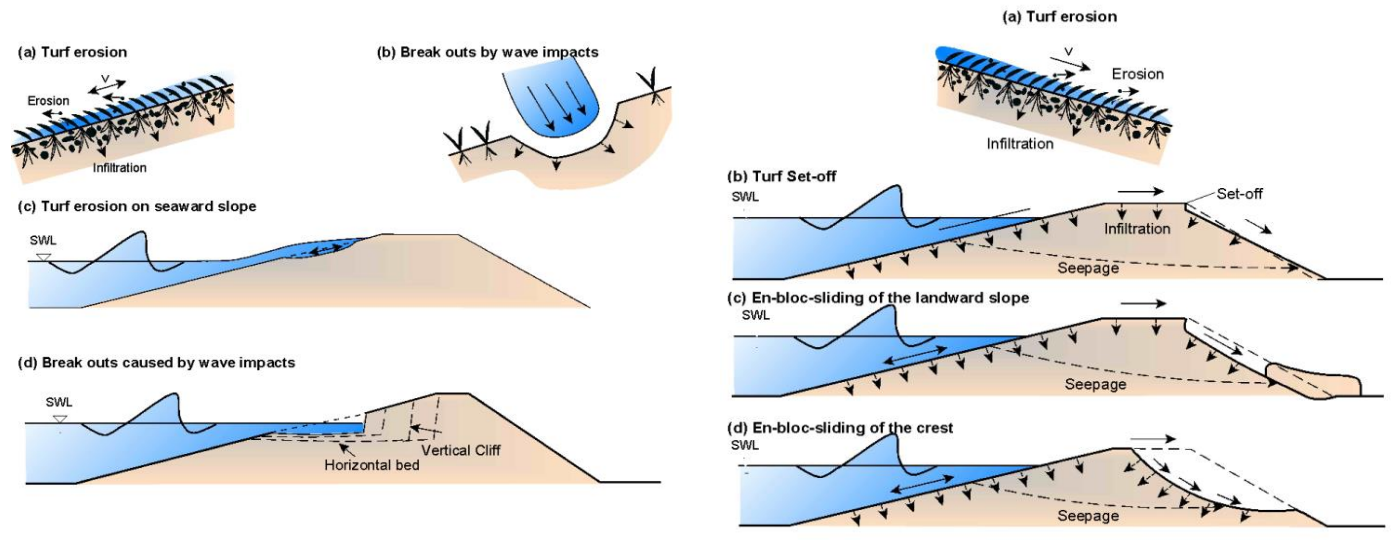

(e) Partial dike breach
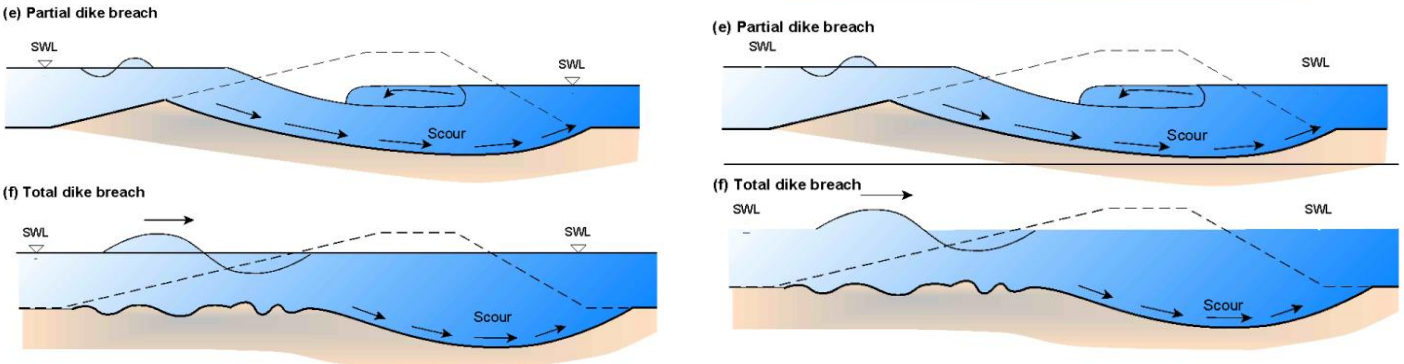

Figure 1. Development of a dike breach on the seaward slope (left) and the landward slope (right) (Schüttrumpf and Oumeraci, 2004).

The task of the planned early warning system EarlyDike is to identify any water infiltration through and deformation of the landward clay cover as soon as possible. As mentioned above, an early identification of deterioration, damage or initial dike failure allows the responsible coastal authorities to avoid dike breaches by early interventions or reduce the damage when a dike failure cannot be prevented anymore. Based on the described differentiation regarding sea dike performance and their potential failure, Fig. 2 shows the capability of an early warning system and where in the chain of events it can take effect. 


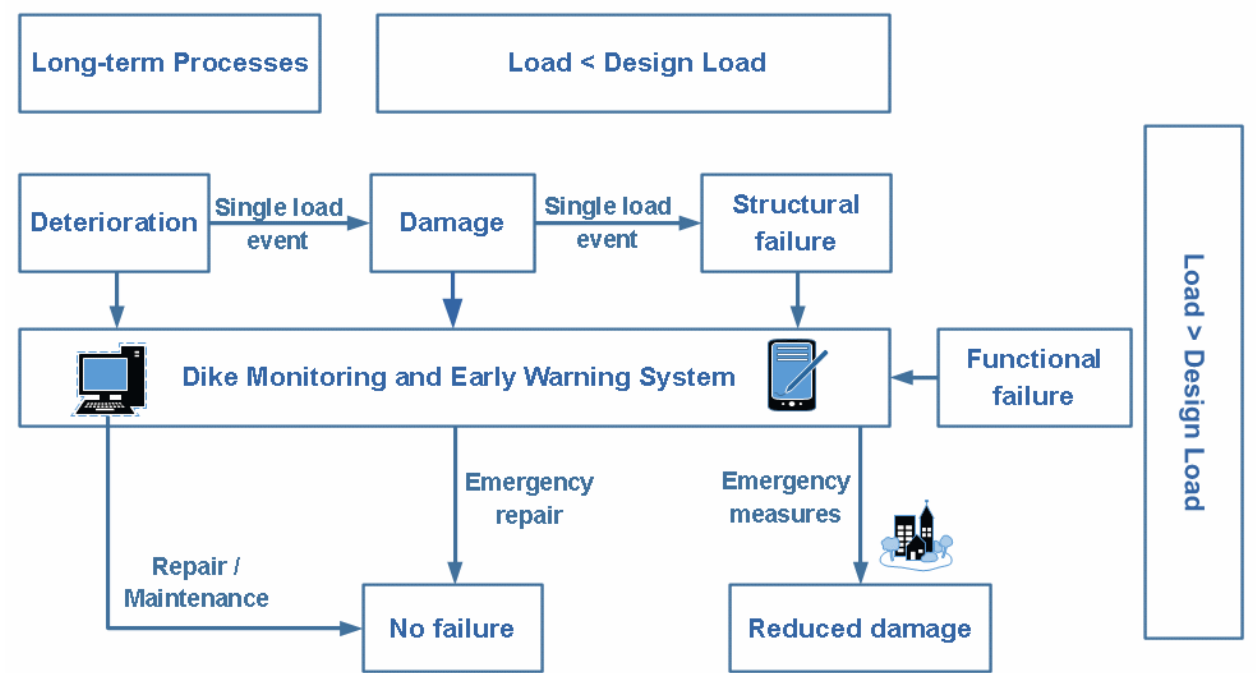

Figure 2. Potential of Early Warning System during the processes that might lead to dike failure.

\section{Dike Monitoring}

Dike safety standards and the common dike monitoring practice in Germany are defined in DWA M 507-1 (2011). It should not be neglected, that these regulations have been made for riverine dikes. However, since the responsibilities for sea dikes are at federal state level, there is no generally valid guidance concerning the monitoring practice for sea dikes in Germany. The common dike monitoring consists of height measurements and cover monitoring. Height measurements are conducted once every ten years. As dikes can be subject to subsidence and settlement, the purpose of height measurements is to observe changes and verify if the dike height is still sufficient to guarantee dike safety (CIRIA 2013).

As an intact cover prevents erosion and inhibits infiltration and sliding, the cover condition is an important indicator for dike stability (CIRIA 2013). Visual inspection of the cover focuses on a variety of anomalies including any kind of visible damage or signs of burrowing animals as well as the condition of the vegetation, adjoining structures and paths on the dike. Additionally, seepage, which might be seen in rising water levels in the inland, is monitored. Because visual inspection requires good meteorological conditions, DWA M 507-1 (2011) recommends conducting the visual inspection during spring. Regulations on the frequency of visual dike inspection are made by the federal states. However, reports on the safety of every dike of high and medium safety classification must be written and handed in at least once a year; reports on the safety of every dike of a low safety classification at least once every five years. Additionally, visual inspection is required in the aftermath of every extreme event (e.g. storm surge).

During extreme events the focus of visual inspection shifts. A different set of indicators for dike stability is recommended: it includes freeboard, erosion damage and the accumulation of ice on the seaward side, sliding soil both on the seaward and landward side, seepage, swelling funnel formation and major soil cracks on the landward side (DWA M 507-1 2011). Bad weather conditions and the quantity of dike length make it hard to keep track of all these indicators just by visual inspection. This means that a continuous dike monitoring is not yet possible. However, continuous monitoring should be considered as a safety improvement for dikes with high safety classification and special safety requirements.

Dike safety is a global issue and recently worldwide effort has been put into the development of more sophisticated dike monitoring systems, which aim to provide a continuous and reliable dike assessment tool. According to Cundill (2016) dike monitoring concepts can generally be divided into intrusive and non-intrusive (or remote) sensing concepts. For non-intrusive sensing concepts, multispectral, thermal, microwave, or LiDAR sensing technology are employed to derive information about the condition of a dike (e.g. Cundill 2016, Koelewijn et Peters 2012, Ohle et. al. 2006, Royet et al. 2013). For intrusive sensing concepts, different types of sensors are integrated into the dike body to measure characteristic values like temperature, pore water pressure, and inclination. Different data analysis methods ranging from simple plotting of measurements against time up to anomaly detection 
and simulation with artificial intelligence have been applied (e.g. Koelewijn et al. 2013, Pengel et al. 2013, Peters et van der Vliet 2009, Simm et al. 2012b, Xiao and Huang 2013).

Although there does already exist a variety of products and for the most methods case studies have shown great potential of improving dike safety, there has not yet been found a suitable and cost-effective dike monitoring system, which reached state of the art and is applicable to a larger stretch of dike line.

\section{THE EARLYDIKE PROJECT}

Nowadays, early warning systems are based on water level observations and predictions only. Although it is well understood, that wind waves, currents and the resistance of sea dikes itself play a pivotal role in dike safety, they are not part of the existing early warning systems. Therefore, it is required to set-up an early warning system considering all parts by combining different sensor data, prediction models, marine data infrastructures, and smart technologies.

The interdisciplinary research project, EarlyDike, has the aim to develop an innovative early warning system (EWS), which works not only based on water level forecasts, but also considers wave load, improved storm surge monitoring, and inner dike conditions. The implementation of a web-based GeoPortal, which integrates the information generated by sensors and numerical simulations, enables decision makers to access reliable real-time data. Thereby, the intended sensor- and risk-based early warning system allows in time warnings and improves present disaster prevention and management. To achieve these objectives five work-packages (WP) have been defined.

1. WP 1: Storm Surge Monitor and Simulator: Development of a statistical storm surge model by using observation and model data as a basis for a storm surge simulator

2. WP 2: Wave Monitor and Simulator: Development of a statistical wave model by using observation and model data as a basis for a wave simulator

3. WP 3: Dike Monitor and Dike Simulator: Real-time Monitoring of sea dikes and testing of smart geotextiles

4. WP 4: Flood Simulator and Flood Damage Simulator: Real-time prediction of inundation areas and expected damage

5. WP 5: Geo-Portal, Sensor and Spatial Data Infrastructure: Access point to sensor and spatial data including web- and smartphone based connection to end-user

An outline of the project is given in Fig. 3. This paper focuses on the development of a dike monitoring system with smart geotextiles, which is ongoing work within work package 3 .

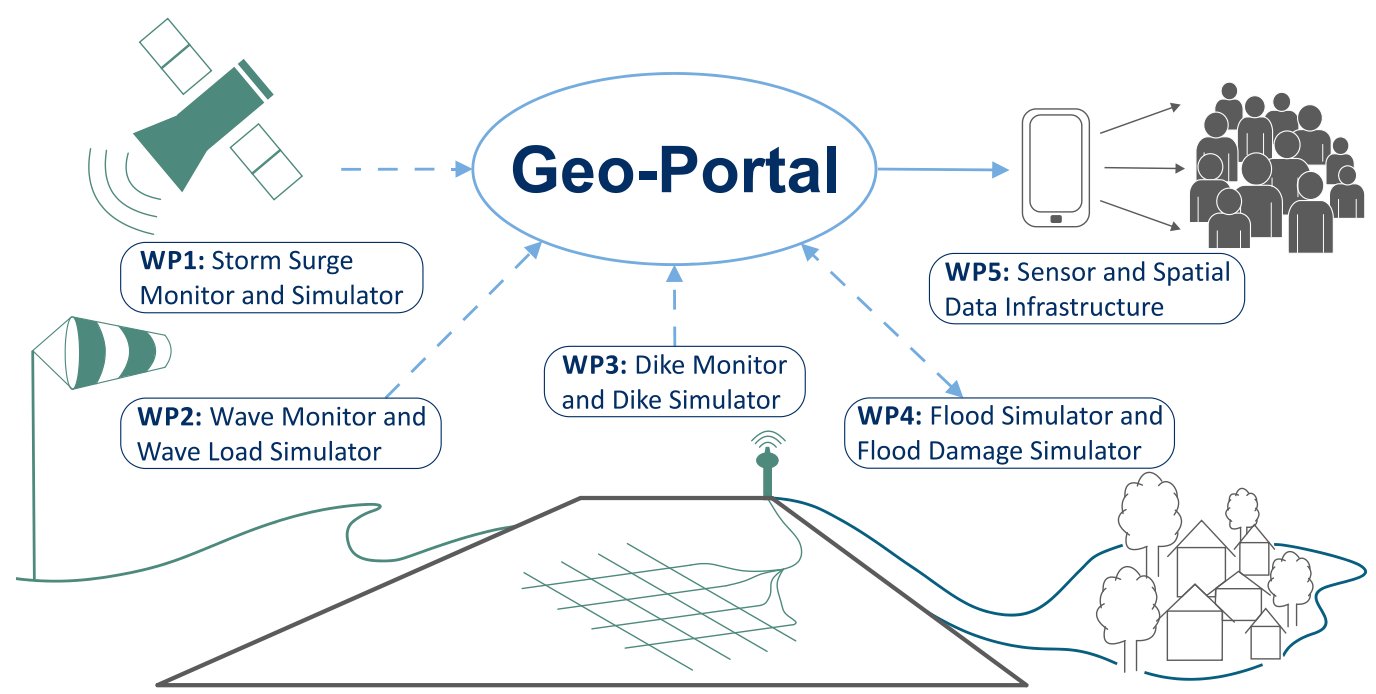

Figure 3. Overview of all work-packages in EarlyDike.

\section{Dike Monitor and Dike Simulator}

As previously described in detail, in Germany monitoring of sea dikes is commonly performed visually after storm surges. To establish the EarlyDike system, a more sophisticated monitoring system, which is able to cover many kilometers of sea dike lengths and supplies the Geo-Portal with real-time data on inner dike conditions, is required. 
The monitoring system, which is developed at the Institute of Hydraulic Engineering and Water Resources Management at RWTH Aachen University (IWW), is based on the detection of two physical properties: water content and deformation. The identification of these parameters is carried out by smart geotextiles, designed in cooperation with the Institut für Textiltechnik (also RWTH Aachen University). The smart geotextiles can be installed beneath the grass cover on the landward slope of a sea dike where they allow detection of water leakages and identification of areas of reduced stability (compare Fig. 4).

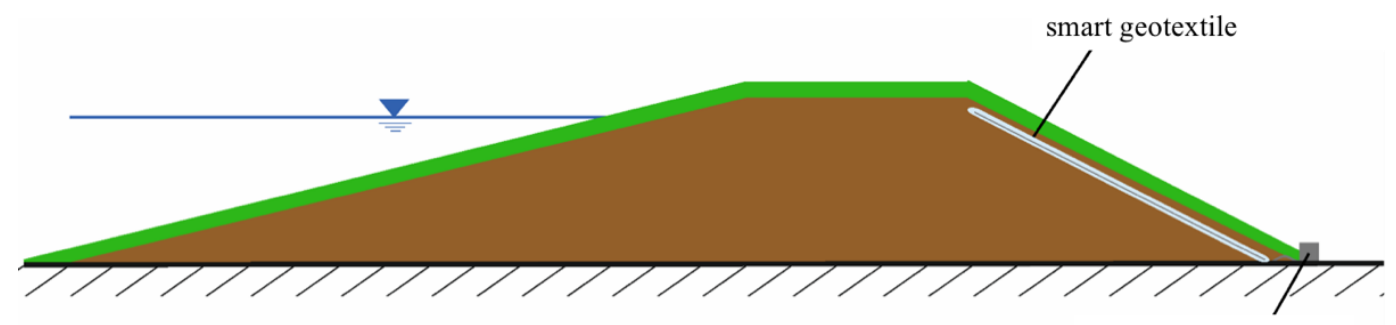

measurement system

Figure 4. Intended placement of smart geotextile within dike body.

\section{Design of Intelligent Geotextiles}

The smart textiles consist of yarn based carbon sensors placed on a geotextile substrate by using embroidery. To generate digital data on inner dike condition, physical parameters need to be transferred into electrical signals (voltage). Two different types of sensors are developed:

1. Water content sensors based on differential measuring between two rovings

2. Deformation sensors based on potential measuring along one roving

Sensors for the determination of water content consist of uninsulated carbon fibers attached in parallel lines to the geotextile. A defined electrical resistance is applied between two fibers each. Once water fills the area between two fibers, electrical resistance is significantly reduced, and the voltage signal decreases. A small-scale prototype of the geotextile sensor and a scheme of the underlying electrical circuit can be seen in Fig. 5.

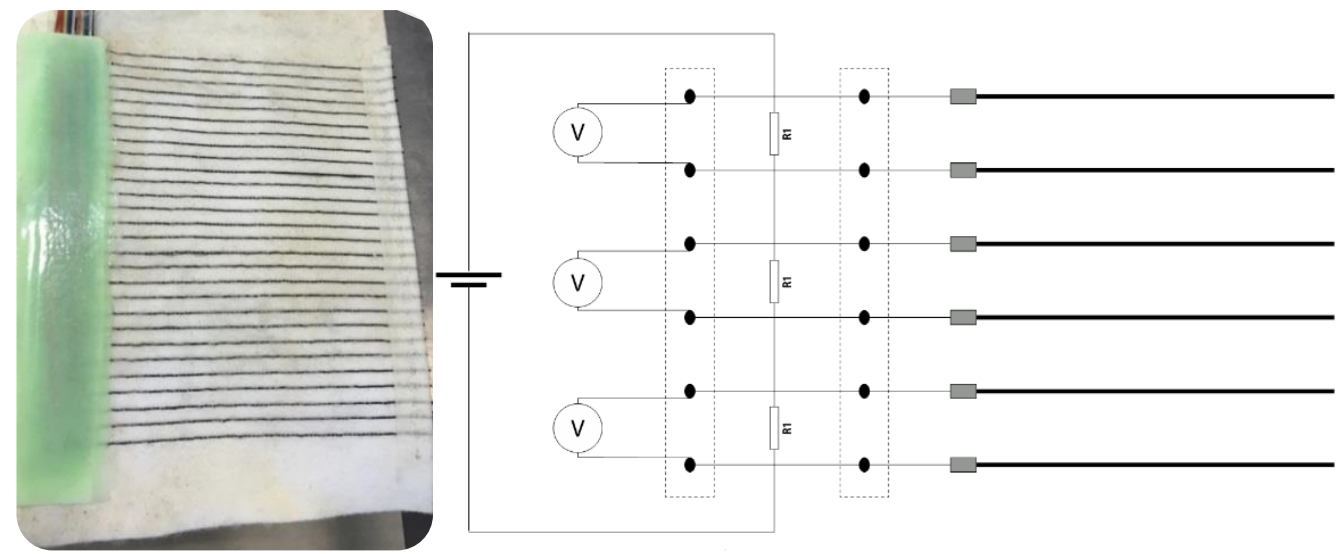

Figure 5. Prototype of geotextile sensor (left) and diagram of underlying circuit (right) for water content sensor.

Deformation sensors consist of insulated carbon fibers (signal influence by humidity should be avoided) stitched on the geotextile. The electrical signal is now measured along one sensor fiber only. Once the fiber gets stretched, its electrical properties change. Detected changes in electrical resistance of these fibers can then be transferred into length deformation.

\section{MODEL SET-UP}

To test the smart geotextiles, extensive laboratory tests are carried out at $I W W$. The test program consists of physical models on three different scales: microscale laboratory testing, macroscale laboratory testing, and in-situ testing (Fig. 6). 


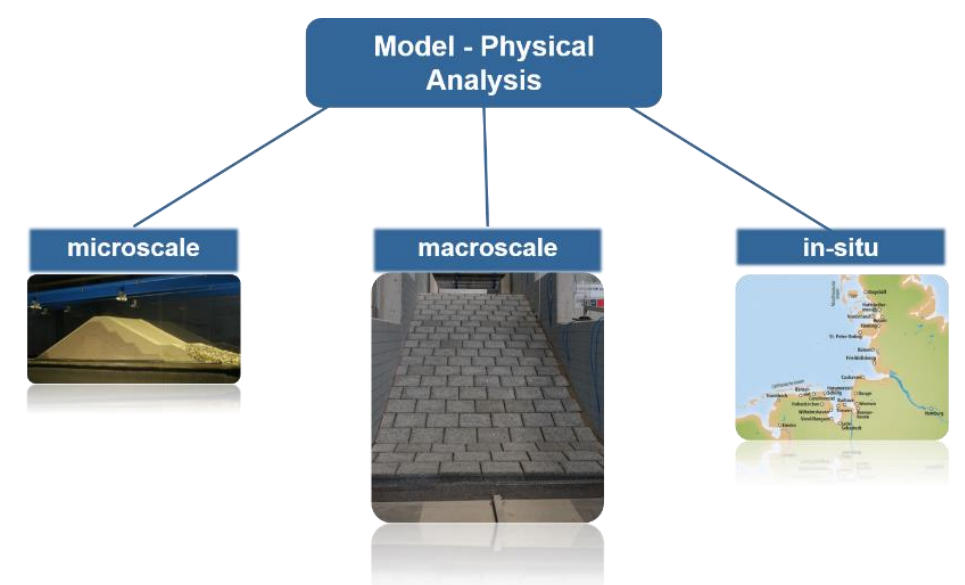

Figure 6. Laboratory investigations on three different scales.

\section{Small-scale Dike Model}

On the smallest scale, tests are performed in a channel of $30 \mathrm{~cm}$ height and $30 \mathrm{~cm}$ width. A model dike, consisting of a homogenous sand body with a height of $20 \mathrm{~cm}$, is installed in the channel. In the first set-up, 20 prototype carbon sensors, stitched on a $40 \mathrm{~cm}$ x $40 \mathrm{~cm}$ geotextile, are placed into the landward slope of the model dike, from which twelve are connected to the measurement unit (compare Fig. 7 and 8).

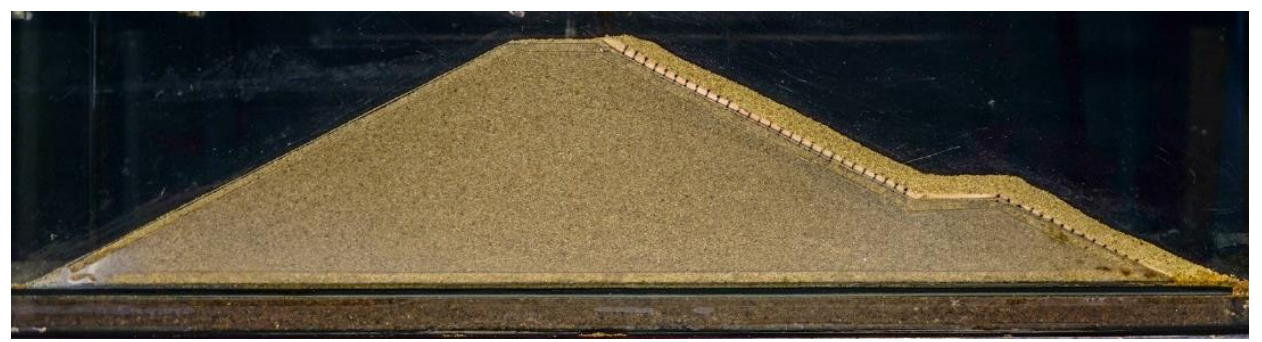

Figure 7. Small-scale dike model from the front side: Homogenous sand body with sensor geotextile installed on the landward slope.

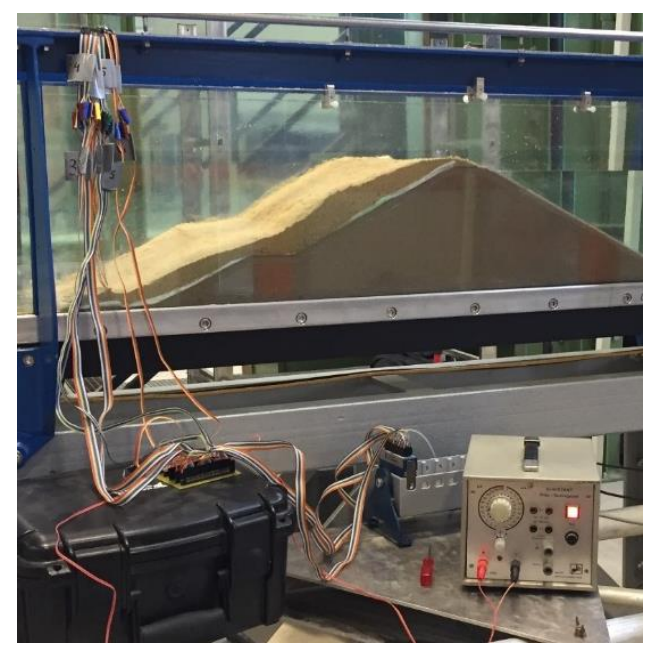

Figure 8. Small-scale dike model from the back side: Installation of dike body in the channel (background) and measurement instrumentation (foreground).

The channel is filled with water until the water level reaches the dike crest; afterwards the water level is kept constant. Without any sealing, the homogenous sand body allows water percolation and the development of seepage lines (compare Fig. 13) can be observed by a camera. During the entire 
experiment, voltage between two carbon fibers each is measured and data collected to detect water percolating through the dike. The position of the measured channels is shown in Fig. 9.

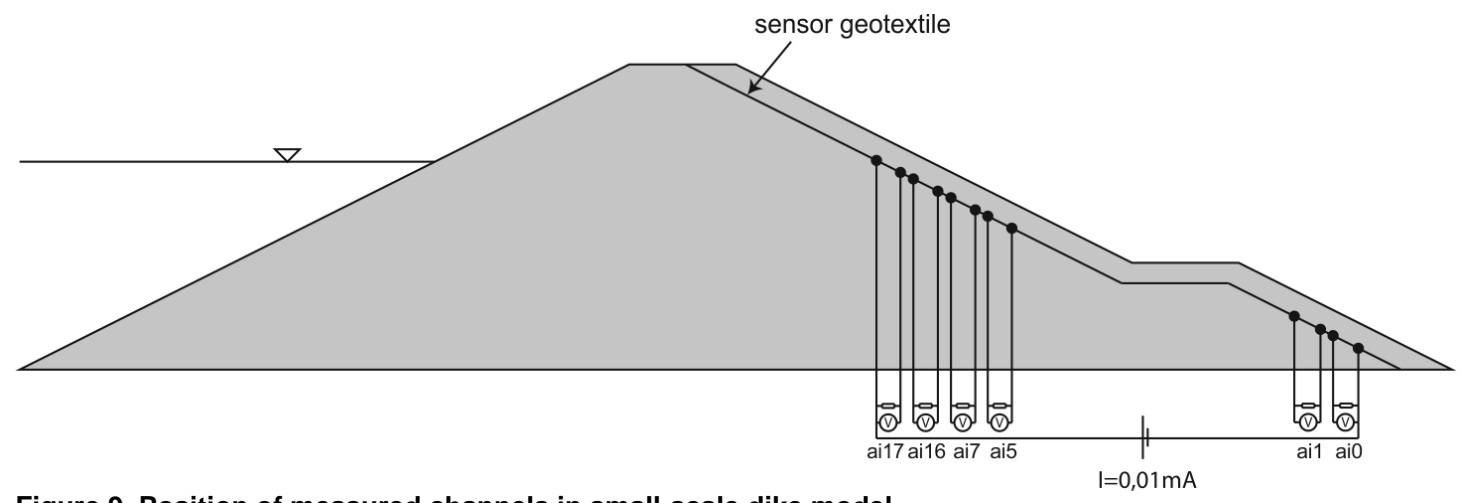

Figure 9. Position of measured channels in small-scale dike model.

The primary objective of the small-scale laboratory tests is the general proof of concept. Furthermore, the experiments enable to gain experience with the measurement method and to undertake improvements of the system, where necessary.

\section{Large-scale Laboratory Tests}

Only investigations on a scale comparable to in situ applications can prove functionality and robustness of the smart geotextiles, as model effects on a small scale cannot be neglected. Therefore, large scale laboratory tests are scheduled and a large-scale dike model has been built up in the laboratory of the Institute of Hydraulic Engineering and Water Resources Management at RWTH Aachen University $(I W W)$. The model consists of a concrete channel of $20 \mathrm{~m}$ length, $2 \mathrm{~m}$ width and up to $3 \mathrm{~m}$ height. Inside the channel dikes with heights up to $2 \mathrm{~m}$, various slopes and different types of cover layers or sealing can be constructed and tested. As the designed dike monitoring system aims to install sensors on the landward side of the dike and the main investigation within the project focuses on failure mechanisms evolving from the landward side, processes on the seaward side can be neglected. Accordingly, within the model only half of the dike body (dike crest and landward slope) is constructed, which makes the experiments less space-, time-, and material consuming. A cross-section of the model dike can be seen in Fig. 10. It should be marked that the shown dike structure is only exemplary and other compositions are possible (e.g. different sealing or revetment structure). Fig. 11 shows the entire model with a revetment layer made of interlocked concrete blocks and a sealing core made of plastic sheet piling.

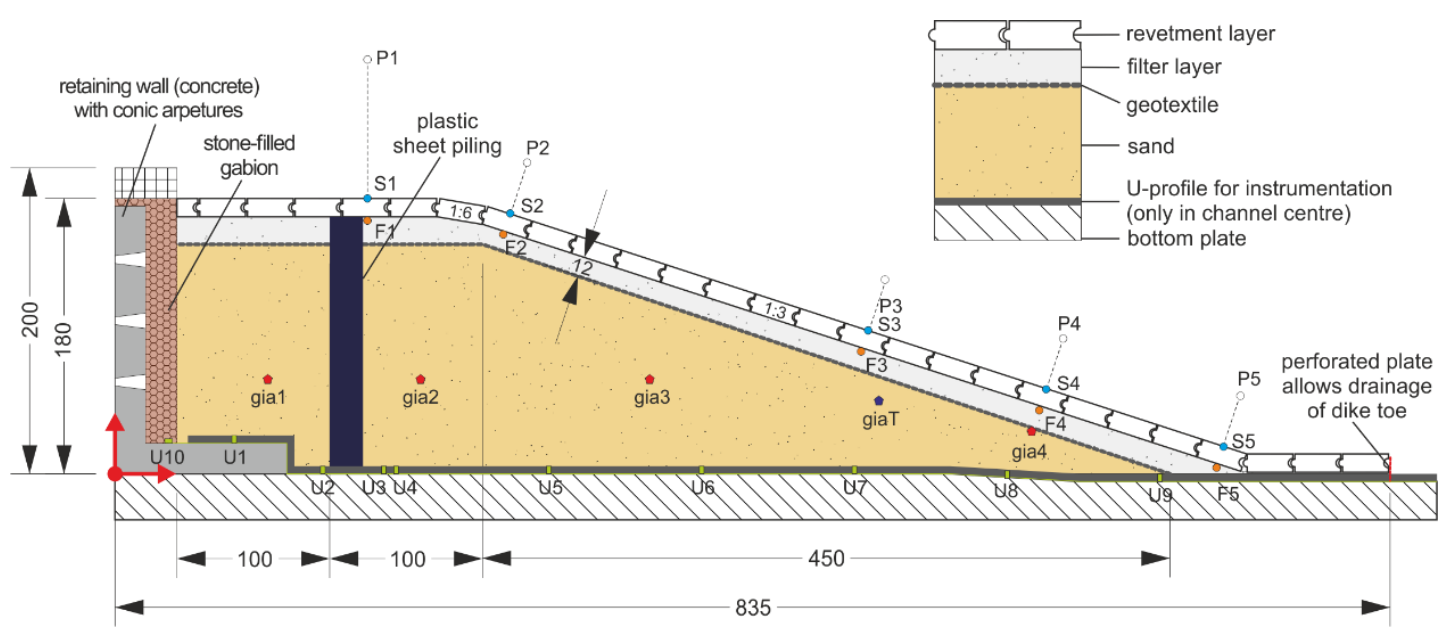

Figure 10. Cross-section of large-scale dike model (marked points show installed instrumentation, Table 1 lists instrumentation details), all dimensions in $\mathrm{cm}$. 

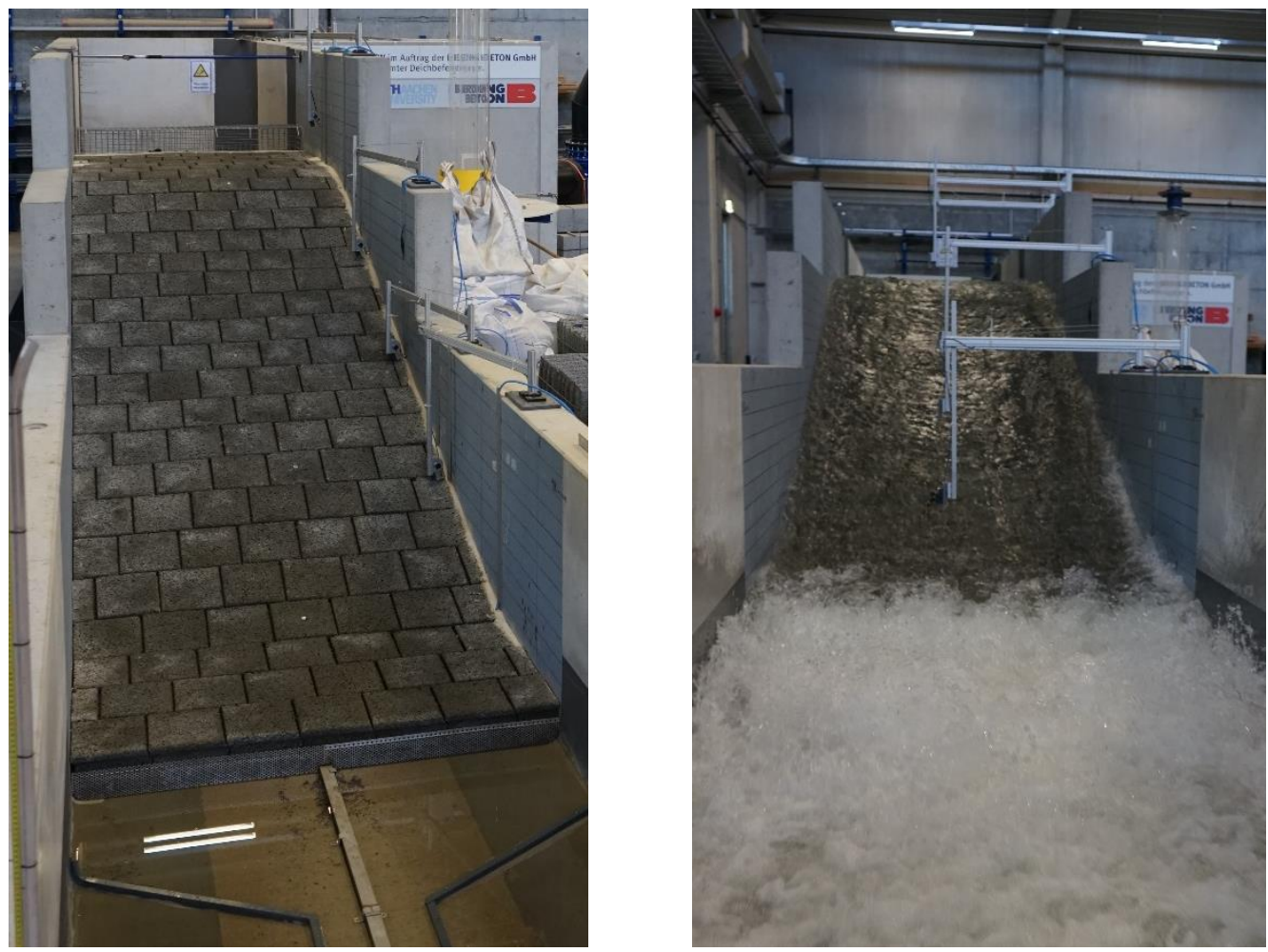

Figure 11. Large-scale dike model (left: overview; right: during overflow event, instrumentation in use).

The design of the model provides for investigations on seepage and overflow events. By filling the reservoir in front of the dike, percolation through the dike can be simulated with different water levels. An automatic filling system guarantees a stable water level, which permits to run experiments with a constant water level over long periods such as several days. The main inlet of the model is attached to the laboratory water circuit. Discharges up to $1,200 \mathrm{l} / \mathrm{s}$ generate repeatable overflow events on dike crest and landward slope.

To validate, that the geotextile sensors deliver reasonable results, knowledge on the ongoing processes inside the dike is inevitable. Therefore, the model dike is equipped with various conventional instrumentation to measure physical processes such as percolation, induced loads, and deformation of the dike. An overview of the installed instrumentation and the measured parameters is given in Table 1 . The smart geotextiles on the large scale are about to be produced and have so far not been tested in the model.

\begin{tabular}{|l|l|l|}
\hline \multicolumn{3}{|l|}{ Table 1. Installed Instrumentation on and in large-scale dike model (for positions compare Fig. 8). } \\
\hline Instrumentation & Measured Parameter & Position \\
\hline Pressure scanning on the ground & Seepage line & U1 - U10 \\
\hline Ultrasonic probes & Water level on dike crest and slope & P1 - P5 \\
\hline Pressure cells & Pressure on revetment & S1 - S5 \\
\hline Pressure cells & Water pressure inside filter layer & F1 - F5 \\
\hline Void Fracture Measurement System (VFMS) & Velocities during overflow events & P1 - P5 \\
\hline Temperature and soil humidity sensors & Soil temperature and humidity & GiaT, gia1 - gia4 \\
\hline Volumetric measurement at end of channel & Amount of seepage water & Outside cross-section \\
\hline Optical methods (photogrammetry) & Deformation of dike crest and slope & $\begin{array}{l}\text { Numerous pictures taken } \\
\text { from different positions }\end{array}$ \\
\hline
\end{tabular}

\section{PRELIMINARY RESULTS}

The following paragraph shortly summarizes obtained results. As the work within the project is still ongoing, the results are preliminary and further investigation will follow. So far, the smart geotextiles have been tested within small-scale experiments. However, results from preliminary investigations 
within the large-scale dike model are presented as well, which concentrate on the evaluation of the conventional instrumentation.

\section{Small-scale Laboratory Tests}

Fig. 12 shows the landward slope of the small-scale model dike during one of the percolation experiments. From left to right: placement of the geotextile within the model dike, water emerging at the landward slope and first steps of backward erosion as a consequence of the rising water level in front of the dike.
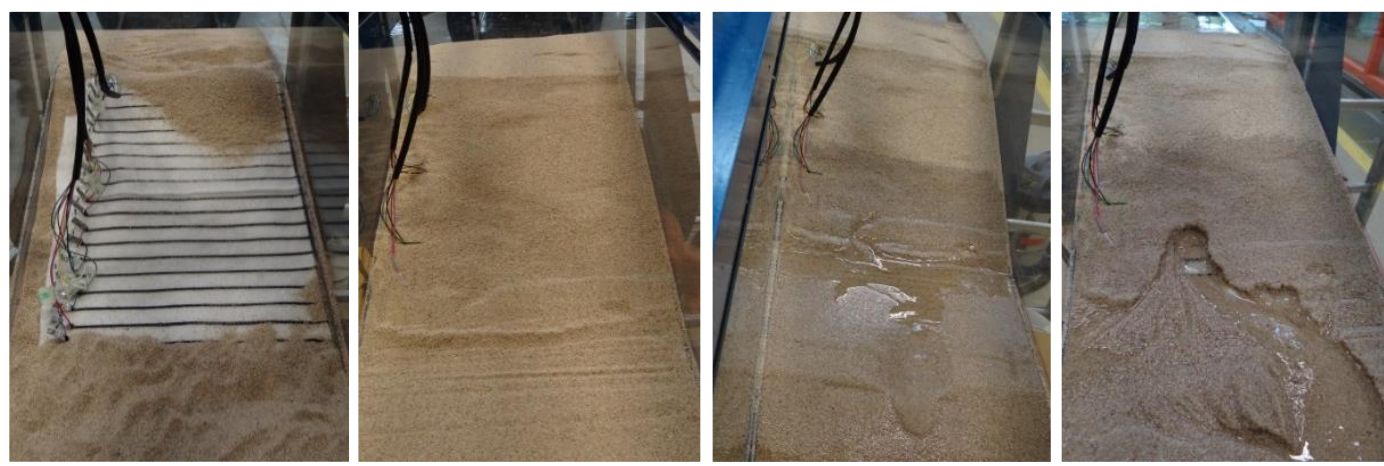

Figure 12. Placement of smart geotextile on the landward slope of small-scale dike model and development of water emersion and sand erosion at landward slope.

The pictures in Fig. 13, taken from the front side, show the propagation of the seepage line within the dike body for different time steps.
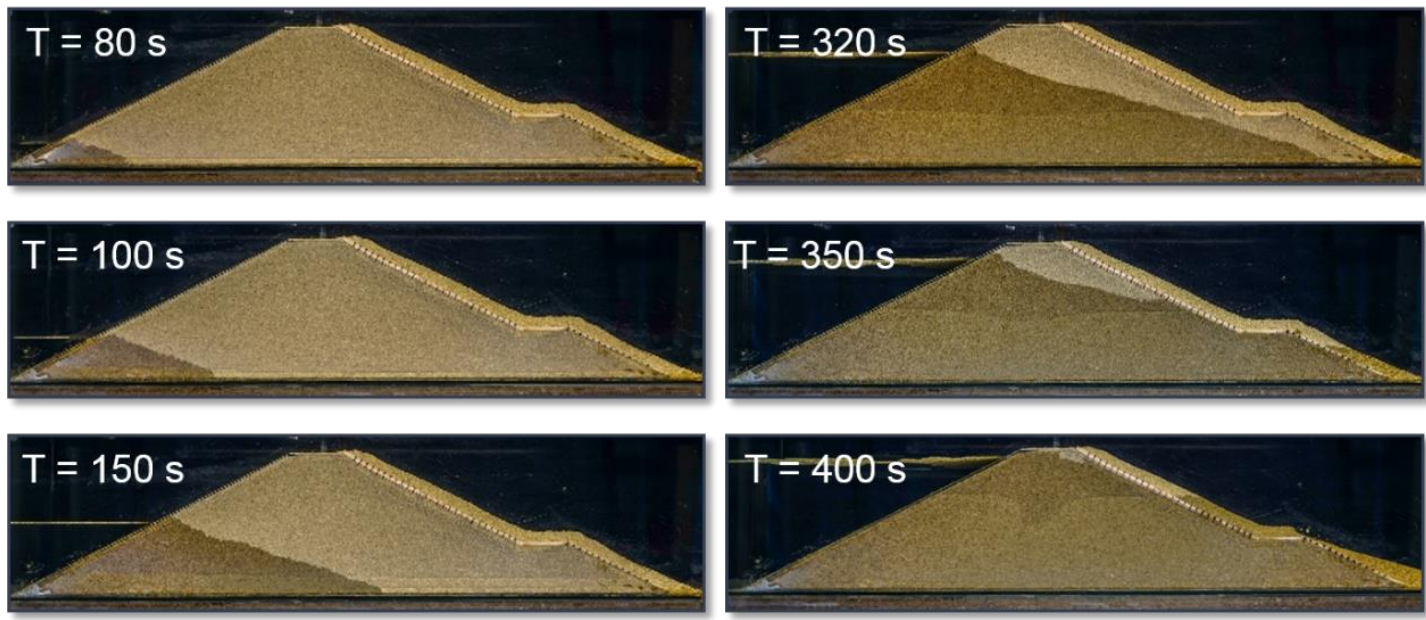

Figure 13. Propagation of seepage line in the small-scale dike model for different time steps, sensor geotextile is installed on the landward slope.

The corresponding results of the measurements are summarized in Fig. 14. In addition to the rising water level in front of the dike (measured by an ultrasonic probe), signals (voltage) from six sensor channels are plotted. The position of the channels and their numbers are labeled in Fig. 9. Channel ai0 refers to the sensor pair at the dike toe, channel ai17 to the one that is closest to the dike crest. Voltage drops at different time steps show the emersion point of the seepage line rising on the landward slope of the dike. 


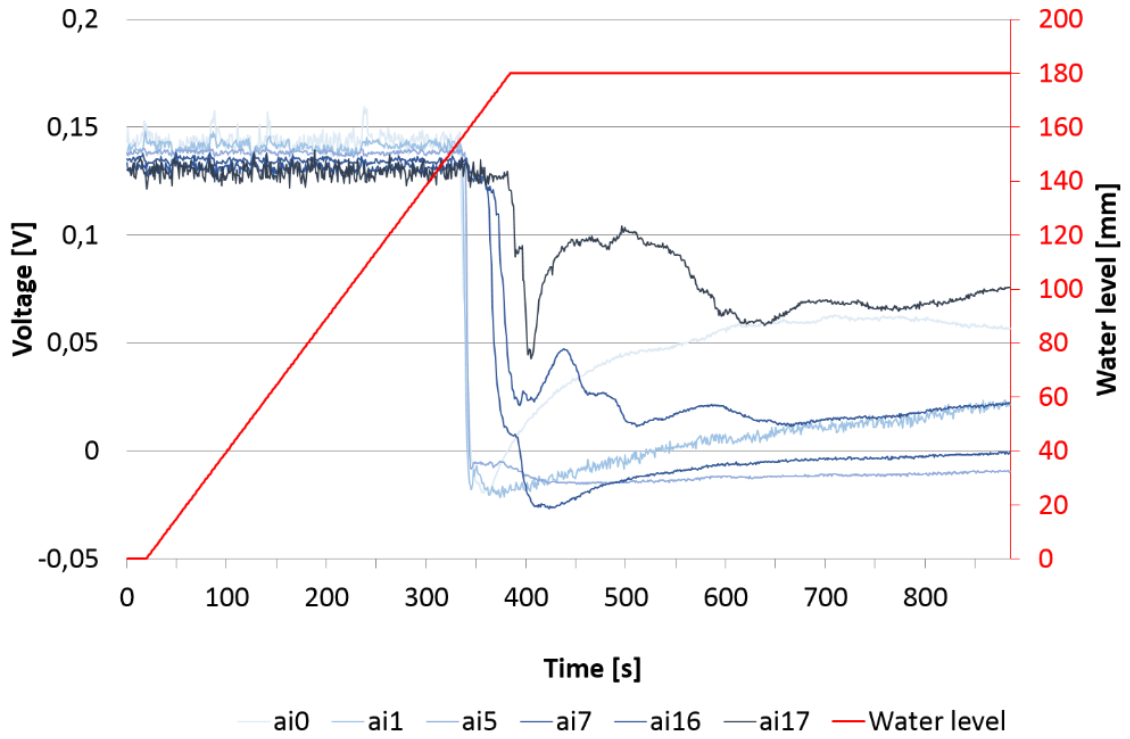

Figure 14. Sensor response to water percolating through the dike.

\section{Large-scale Laboratory Tests}

The following graphs show results from the preliminary tests with the large-scale dike model, although to date geotextile sensors have not been implemented. However, in order to test the model and the conventional measurement instrumentation, experiments were run for two loading events: percolation and overflow. Additionally, damage has been triggered by pulling five interlocked stones out of the revetment and afterwards generating overflow on the previously destroyed revetment.

Fig. 15 indicates the location of the seepage line inside the dike model for a steady-state water level of $167 \mathrm{~cm}$ in front of the dike, which has been calculated from the results of the pressure scanner on the bottom of the concrete channel. Within this test, the dike consists of a homogenous sand body with an overflow-stable revetment layer (consisting of geotextile, filter layer, and interlocked concrete blocks). The sealing core is made of plastic sheet piling with unsealed interlocks.

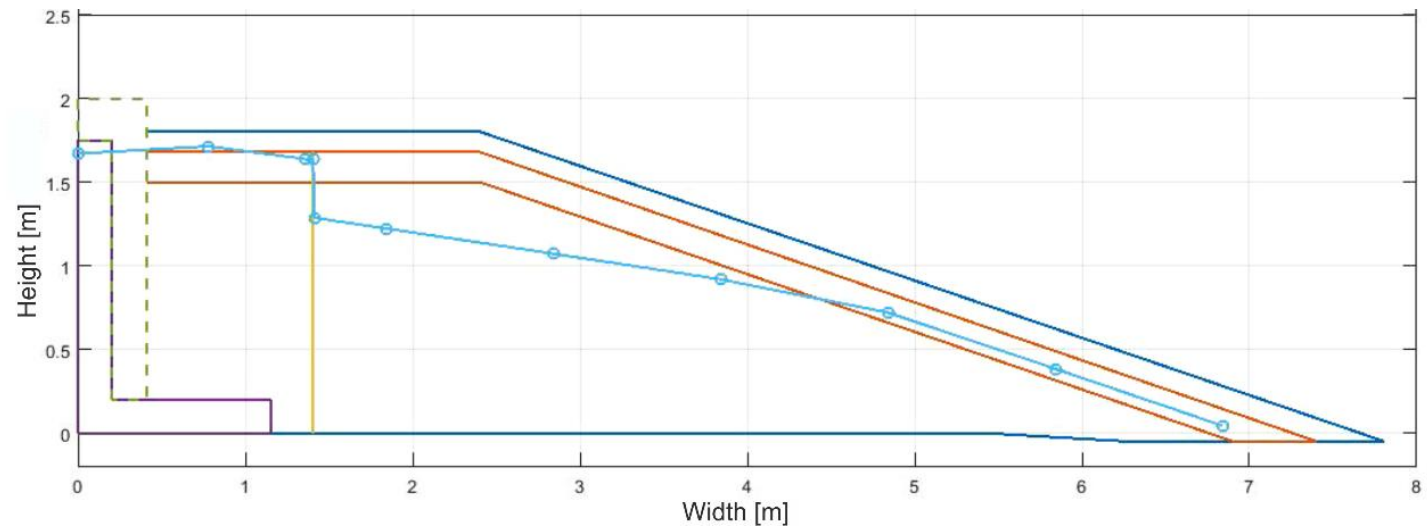

Figure 15. Measured height of steady-state seepage line inside the large-scale dike model during percolation event $\left(H_{\text {water }}=1.67 \mathrm{~m}\right)$. Dike revetment consisting of filter layer and interlocked concrete blocks. Inner sealing: plastic sheet pile with permeable locks.

Fig. 16 illustrates the deformation of the dike after having pulled the first interlocked stone out of the revetment. The graph shows the comparison of the dike height between the initial state and the state after having pulled out the stone. It can be clearly seen, that adjacent parts have been lifted as well, which is due to the interlocking characteristics of the revetment. Apart from that, settlements on the dike crest are visible, which can be traced back to inner shifting as the filter layer has been washed out partly once the revetment stone was absent. 


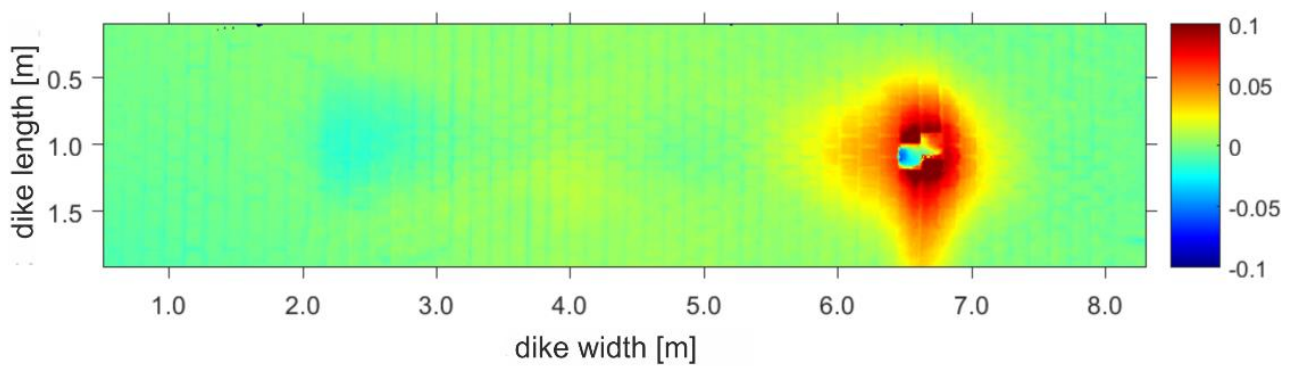

Figure 16. Deformation of dike surface after locally imposed damage, absolute height difference shown in $\mathrm{m}$.

Fig. 17 shows the condition of the dike after generating overflow of $500 \mathrm{l} / \mathrm{s}$ for about an hour on the previously damaged revetment. Over time, the filter material was washed out through the gaps in the revetment layer, which resulted from the five extracted stones. Once the filter layer was absent, geotextile and revetment stones were lifted by the inner water pressure and the sand core started to erode. In order to prevent a total dike breach, the inlet was closed at the moment sand core erosion started. How fast the processes went, once the filter layer was absent, can be seen at the amount of sand erosion that has still appeared.

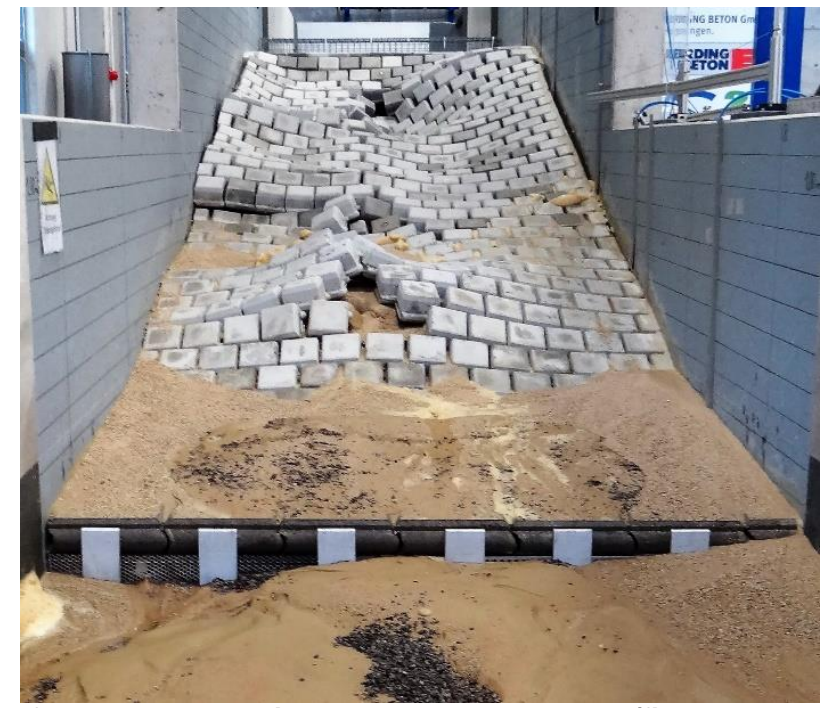

Figure 17. Dike after overflow event on previously damaged revetment (five stones had been pulled out).

The deformation of the dike after the failure event in comparison to the initial state is plotted in Fig. 18. The processes, which had already started after pulling the first stone, proceeded. The subsidence of the dike crest increased whereas the lower part of the slope was lifted due to the inner shifting of material.

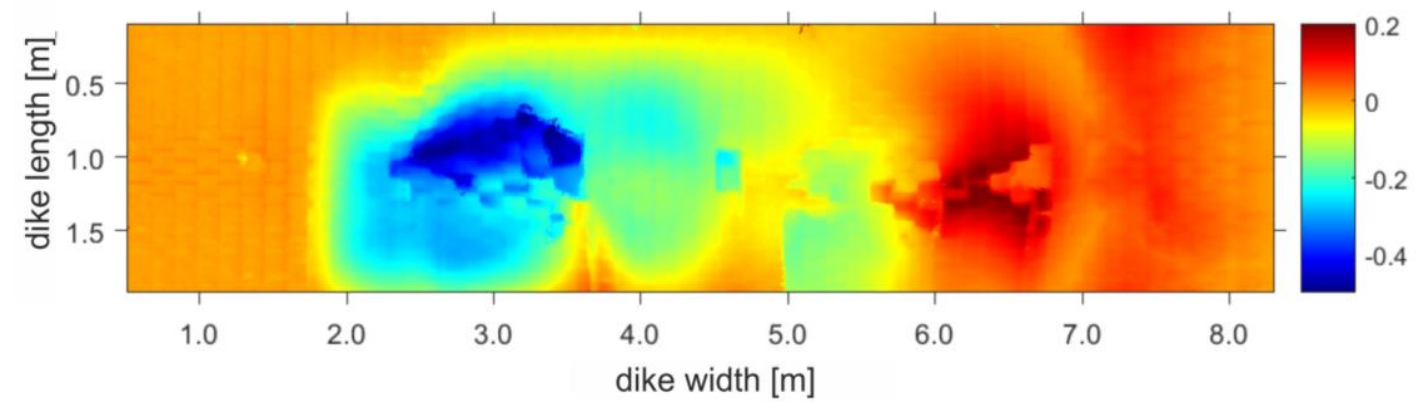

Figure 18. Deformation of dike surface after overflow event on previously damaged revetment (five stones had been pulled out), absolute height difference shown in $\mathrm{m}$. 


\section{DISCUSSION}

As there have not yet been conducted any experiments with sensors on the large scale the discussion is limited to the small-scale investigations.

It is obviously that model effects on such a small scale cannot be neglected. But the aim of the smallscale model is not to investigate on percolation processes in general but to validate the functionality of the sensors. For this, the model is suitable and even offers a few advantages over large-scale investigations: Percolation processes through the dike body occur much faster, which makes the tests less time-consuming. The whole set-up can be build up within a few minutes and without the use of construction machines the sand core material can be changed, dried etc. Furthermore, percolation processes can be easily observed from the outside. The use of any measurement instrumentation apart from a camera and one ultrasonic probe is not necessary. By a camera alone, percolation processes can be documented, which enables a good and straightforward optical validation of the sensors (compare Fig. 13).

The small-scale investigations have shown a general functionality of the smart geotextile, although some problems have been faced, which have resulted in minor improvements of the measuring concepts: With the first prototype, it is only possible to detect the water content changes with reliable accuracy in initially dry sand. In experiments with initially humid sand, there can still be seen a voltage drop when percolation reached the sensors, but this voltage drop is lower and the noise within the data makes it impossible to determine the height of the water emersion accurately. This can be traced back to leak currents between the sensors. As all sensors are uninsulated and the current is applied to all sensors at the same time, it cannot be prevented that current flows occur between sensors that are not direct neighbors. Further tests on that problem show, that on the small scale one roving is influenced by up to eight adjacent rovings. This problem can be solved by using a multiplexer unit (proposed circuit diagram shown in Fig. 19), so there is never measured more than one roving pair at the same time. On the other hand, the implementation of the smart geotextiles on a larger scale might automatically reduce the problem of interferences between adjacent rovings as the distances between the channels are much larger than a few centimeters.

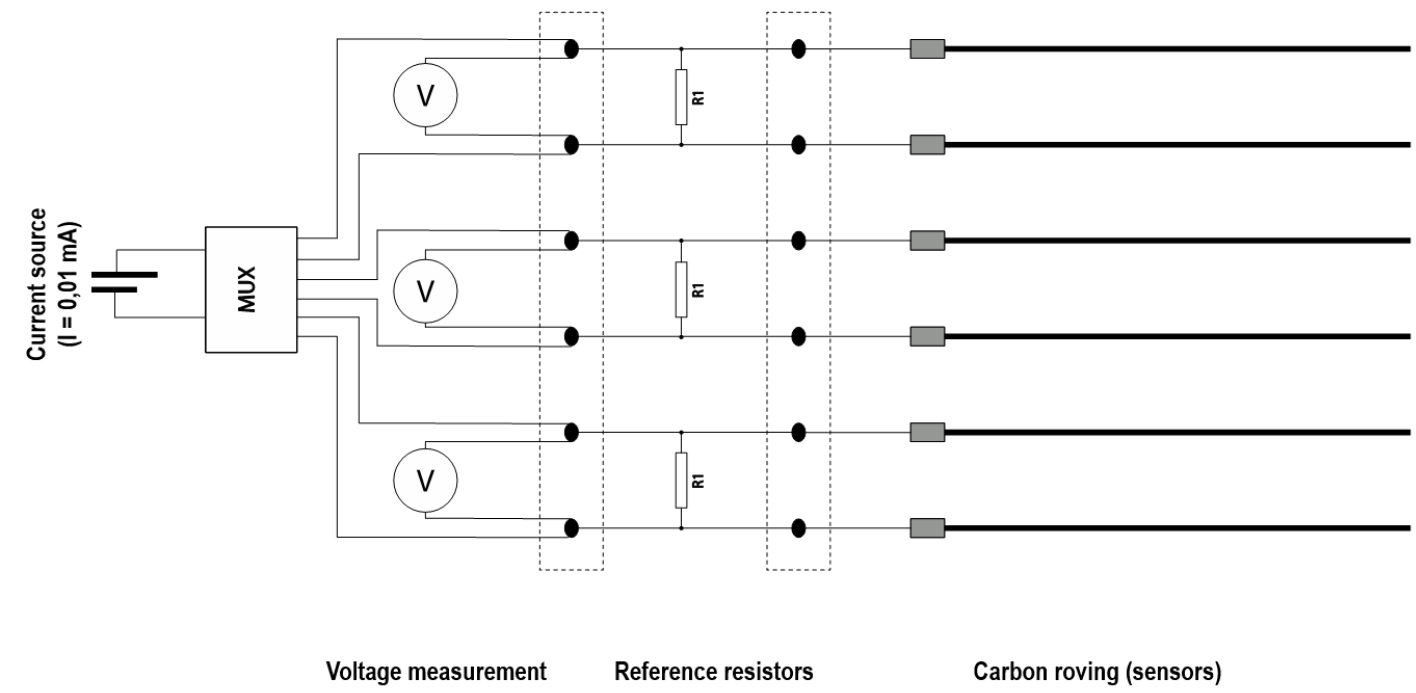

Figure 19. Possible circuit with the use of multiplexer unit.

Another problem is the insufficient shielding of cables and the electronic board of the tested prototype geotextiles. This results in noisy data and the measurement of unreasonable negative potentials. This problem cannot be solved completely by shielding the measurement unit and the connecting cables, as the rovings themselves still need to stay uninsulated. Further knowledge on this must be gained within the large-scale tests. 


\section{SUMMARY AND OUTLOOK}

The interdisciplinary research project, EarlyDike, attempts to develop an innovative early warning system (EWS), which works - in contrast to existing EWS - not only based on water level forecasts, but also considers wave loads, improved storm surge monitoring, and inner dike conditions. The implementation of a web-based Geo-Portal, which integrates the information generated by sensors and numerical simulations, enables decision makers to access reliable real-time data. Thereby, the intended sensor- and risk-based early warning system allows in time warnings and improves present disaster prevention and management.

Objective of this paper was to depict the integration of sensor-based dike monitoring within the project. The common practice of dike monitoring in Germany is based on visual safety inspections, mainly by foot. Under storm conditions this type of assessment is not possible, apart from that, the projected EWS requires a more sophisticated monitoring system, which is able to cover many kilometers of sea dike lengths and supplies the Geo-Portal with real-time data on inner dike conditions, which allow a reliable prediction of possible dike failure.

The planned early warning system is based on the detection of two physical properties: water content and deformation. The identification of these parameters is carried out by smart geotextiles, which consist of yarn based carbon sensors placed on a geotextile substrate by using embroidery. The sensors can be installed beneath the grass cover on the landward slope of a sea dike where they allow detection of water leakages and identification of areas of reduced stability.

In order to validate the new sensors, experimental work in the laboratory of the Institute of Hydraulic Engineering and Water Resources Management at RWTH Aachen University (IWW) is conducted. Small-scale laboratory tests show a general capability of the sensor concept and led to minor improvements of the sensors. Large-scale laboratory tests are projected to gain more information on the sensor feasibility and to develop a sophisticated dike monitoring concept. The erected model dike of $2 \mathrm{~m}$ height, $7 \mathrm{~m}$ width, and $2 \mathrm{~m}$ length is embedded in a concrete channel and allows investigations on overflow events, wave overtopping, and percolation through the dike. As the large-scale model consists of different soil layers, a more precise dike structure, which takes sealing, filter layers, and dike revetment into account, can be mapped. As the functionality of the dike model with all its instrumentation has been tested successfully with several different dike setups, the model is now set-up for the implementation of sensor geotextiles on a large scale. The first large-scale sensor geotextile (compare Fig 20) is in progress and experiments are scheduled for springtime 2017

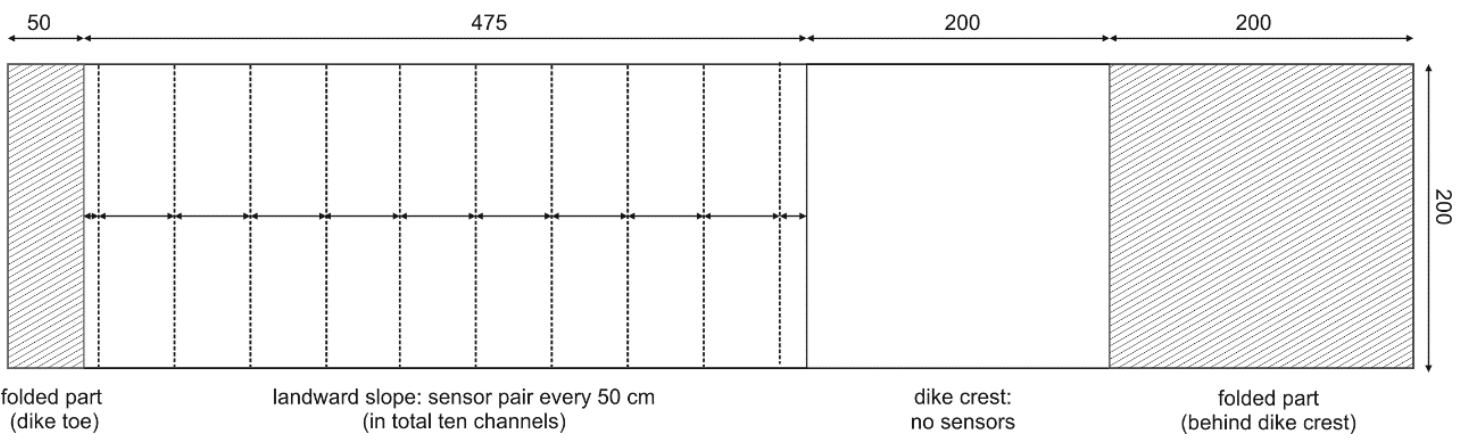

Figure 20. Design of the smart geotextile for the large-scale dike model (dimensions in $\mathrm{cm}$ ).

\section{ACKNOWLEDGMENTS}

The presented work is part of the project EarlyDike, founded by the German Federal Ministry of Education and Research (BMBF) (Project No. 03G0847A).

\section{REFERENCES}

Allsop, W., Kortenhaus, A. and M. Morris. 2007. Failure Mechanisms for Flood Defence Structures FLOODsite Project, Report No. T04-06-01.

Bersan, S., A. R. Koelewijn, and P. Simonini. 2015. Application of distributed temperature sensors in piping-prone dikes, Proceedings of the $9^{\text {th }}$ International Symposium on Field Measurements in Geomechanics, Sydney, 475-486.

CIRIA. 2013. The International Levee Handbook. 
Cundill, S. L. 2016. Investigation of remote sensing for dike inspection, ITC dissertation, number 283, ITC, University of Twente.

DWA M 507-1. 2011. Deiche an Fließgewässern Teil 1: Planung, Bau und Betrieb, DWA-Regelwerk Merkblatt, Deutsche Vereinigung für Wasserwirtschaft, Abwasser und Abfall e. V., Hennef.

Koelewijn, A.R. and D.J. Peters. 2012. Design of IJkdijk All-in-One/Sensor Validation Test, Project 1206242-000, Deltares.

Koelewijn, A.R., de Vries, G. and H. van Lottum. 2013. Full-scale field validation of innovative dike monitoring systems, Proceedings of the $18^{\text {th }}$ International Conference on Soil Mechanics and Geotechnical Engineering, Paris.

Ohle, N., Elsner, A. and C. Zimmermann. 2006. Monitoring of levees using remote sensing technology, Franzius-Mitteilungen No. 92, Ludwig-Franzius-Institute for Hydraulic, Estuarine and Coastal Engineering, Hannover.

Pengel, B.E., Krzhizhanovskaya, V.V., Melnikova, N.B., Shirshov, G.S., Koelewijn, A.R., Pyayt, A.L. and I. I. Mokhov. 2013. Flood early warning system: sensors and internet, In: A. Chavoshian and K. Takeuchi (Eds.). Floods: from risk to opportunity, IAHS publication No. 357, 445-453.

Peters, E. T., and P. P. van der Vliet. 2009. Sensor network Geo-Beads TM serves real time and online geotechnical monitoring of large areas, Proceedings of the International Conference on Landslide Processes: from geomorphologic mapping to dynamic modelling, Strasbourg, CERG Éditions.

Royet, P., Palma Lopes, S., Fauchard, C., Mériaux, P. and L. Auriau. 2013. Rapid and cost-effective dike condition assessment methods: geophysics and remote sensing, report within FloodProBE project, www.floodprobe.eu/partner/assets/documents/Floodprobe-D3.2_V1_4_April_2013.pdf.

Schüttrumpf, H. and H. Oumeraci. 2004. Learning from Sea Dike Failures, PIANC-Bulletin No. 117, 4760.

Schüttrumpf, H. 2008. Sea Dikes in Germany, Die Küste, Archiv für Forschung u. Technik an der Nordu. Ostsee; archive for research and technology on the North Sea and Baltic Coast, Ed. Kuratorium für Forschung im Küsteningenieurwesen, No. 74, 189-199.

Simm, J., Wallis, M, Smith, P, Deniaud, Y, Tourment, R, Veylon, G, Durand, E, McVicker, J and R. Hersh-Burdick. 2012a. The significance of failure modes in the design and management of levees a perspective from the International Levee Handbook team, Proceedings of the $2^{\text {nd }}$ European Conference on Flood Risk Management, FLOODrisk2012, Rotterdam.

Simm, J., Jordan, D., Topple, A., Mokhov, I., Pyayt, A., Abdoun, T., Bennett, V., Broekhuijsen, J. and R. Meijer. 2012b. Interpreting sensor measurements in dikes - experiences from UrbanFlood pilot sites, Proceedings of the $2^{\text {nd }}$ European Conference on Flood Risk Management, FLOODrisk2012, Rotterdam.

Xiao, H. and J. Huang. 2013. Experimental Study of the Applications of Fiber Optic Distributed Temperature Sensors in Detecting Seepage in Soils, Geotechnical Testing Journal, Vol. 36 No. 3, 360-368. 